\title{
Yumuşak kabuklu kaplumbağa evrimi: Akdeniz'deki tek tür, Trionyx triunguis
}

\author{
Özgür GÜÇLÜ1,3,*, Dilek KESKİN²,3 \\ ${ }^{1}$ Adnan Menderes Üniversitesi, Sultanhisar Meslek Yüksekokulu, Aydın, Türkiye \\ ${ }^{2}$ Adnan Menderes Üniversitesi, Köşk Meslek Yüksekokulu, Aydın, Türkiye \\ ${ }^{3}$ Adnan Menderes Üniversitesi, Rekombinant DNA ve Rekombinant Protein Merkezi, Aydın, Türkiye
}

(ORCID: 0000-0001-6176-4715) (ORCID: 0000-0003-2479-0070)

\begin{abstract}
$\ddot{O} z$
Kaplumbağaların vücut morfolojilerinin kökeni sürüngen evriminin en önemli gizemlerinden birini oluşturmaktadır. Günümüze kadar yapılan çeşitli moleküler çalışmalar, kaplumbağaların Tuatara, kertenkele ve yılanların dâhil olduğu Lepidosauria grubunun dışında yer aldığı ve timsah ile kuşların bulunduğu Archosauria grubuna kardeş grup olduğunu ortaya koymuştur. Araştırıcılar kaplumbağaların atası olarak günümüzden 228 milyon yıl öncesine ait olan Eorhynchochelys sinensis isimli yeni bir tür tanımlamışlardır. Modern kaplumbağların günümüzde yaşayan en eski grubu olarak bilinen Güneydoğu Asya orijinli olan Trionychidae familyasına giren kaplumbağalar gece aktif olan etçil tatlı su kaplumbağalarıdır. Karapas ve plastronlarında epidermis orjinli plaklar olmamasına rağmen bu bölgelerin üstü ince bir deri ile örtülüdür. Bu grubun bilinen en eski fosil kaydı (yaklaşık 100-140 MYÖ) Santanachelys gaffneyi'dir. Trionychidae üyeleri Asya kıtasının Kretase jeolojik döneminin başlangıcından günümüze kadar gelen, yüksek oranda morfolojik çeşitlilik gösteren canlılardır.
\end{abstract}

Anahtar kelimeler: Evrim, Trionyx triunguis, Akdeniz.

\section{Evolution of soft-shell tortoise: the only species in the mediterranean, Trionyx triunguis}

\begin{abstract}
Turtles are one of the most important mysteries of the reptilian evolution of body morphology. Various molecular studies conducted up to the daylight revealed that the tortoise group was a group for the Archosauria group where the lepidosauria group, including Tuatara, lizards and snakes, was located outside the group and the crocodiles and birds were found. Researchers have identified a new species named Eorhynchochelys sinensis, the ancestor of turtles, dating back 228 mya. Turtles of Trionychidae originated in Southeast Asia, known as the oldest living group of modern tortoises, are carnivorous fresh water turtles active at night. Although there are no epidermic plaques in the carapace and plastons, these areas are covered with thin skin. The oldest fossil record of this group is Santanachelys gaffneyi (about 100-140 mya). The group members are high-order morphologically diverse organisms that date from the beginning of the cretaceous period of the Asian continent.
\end{abstract}

Keywords: Evolution, Trionyx triunguis, Mediterranean.

\section{Giriș}

Kaplumbağalar, dişsiz, anapsid ve kemik bir kabuk ile üstleri örtülmüş ovipar özellik gösteren sürüngenlerdir. Genellikle üzerlerini örten kemik kabuğun üzeri epidermal plaklarla örtülmüştür. Kaburga kemikleri, leğen kemiği ve göğüs kemiği karapasta birleşmiştir. Klavikula ve interklavikula plastrondaki modifiye edilmiş alt kaburgalarla birleşmiştir. Boyun omurunun çıkıntısı Cryptodira alttakımında kaybolmuştur. Bu alttakımdaki kaplumbağalarda boyun geri çekilir. Pleurodira alttakımına

"Sorumlu yazar: oguclu@adu.edu.tr

Geliş Tarihi: 21.03.2019, Kabul Tarihi: 29.07.2019 
giren kaplumbağalarda boyun omurundaki çıkıntı bulunduğundan boyunlarını geri çekemezler. Bunların yanında bütün kaplumbağalar poikilotherm özellik gösterirler [1].

Güneydoğu Asya orijinli olan Trionychidae familyasına (Yumuşak kabuklu kaplumbağalar) giren kaplumbağalar gece aktif olan etçil tatlı su kaplumbağalarıdır. Bununla birlikte çoğu acı sulara adapte olmuşlardır. Karapas ve plastronlarında epidermis orjinli plaklar olmamasına rağmen bu bölgelerin üstü ince bir deri ile örtülüdür. Gırtlak mukoza zarında yer alan yumak haldeki kapiler damar sistemi ve deri solunumunun yardımı ile suyun altında 15 saate kadar kalabilirler [2]. Familyanın kürek şeklindeki üyelerinin her biri 5 parmaklı, bunların üçünde etkili, sivri tırnaklar mevcuttur. Burunları dışarıya doğru uzamış haldedir ve gözleri başının üst kısmındadır. Karapas ve plastron arasındaki bağlantı yerinde bulunan marjinaller çoğunlukla kaybolmuştur. Plastronda femoral çıkıntılar bulunmaz [3]. Trionychidae içindeki kaplumbağalarda karapas uzunluğu Pelodiscus sinensis'te (Çin yumuşak kabuklu kaplumbağası) olduğu gibi $25 \mathrm{~cm}$ ile Pelochelys cantorii'de (Asya dev yumuşak kabuklu kaplumbağası) olduğu gibi $130 \mathrm{~cm}$ arasında değişiklik gösterir [4]. Asya dev yumuşak kabuklu kaplumbağası ile neredeyse aynı büyüklükte $(1,2 \mathrm{~m})$ olan Trionyx triunguis (Nil Yumuşak Kabuklu Kaplumbağası) kaydı bulunmaktadır [5].

\section{Kaplumbağaların Kökeni}

Yaşayan amniyotların temel gruplarını memeliler, kuşlar, timsahlar, kaplumbağalar, squamatlar ve sphenodontidler oluşturur. Fosil kayıtlardan, amniyotların günümüzden yaklaşık olarak 300 Milyon yıl önce (MYÖ) ortaya çıtıkları, 250 MYÖ ise neredeyse temel grupların hepsinin çeşitlendiği anlaşılmaktadır [6,7]. Morfolojik olarak kaplumbağa, memeli ve kuşlar büyük oranda ilkel sürüngen atalarından türemişlerdir. Kaplumbağaların orijini, amniyot filogenisi ile ilgili çok az bilgi olmasından dolayı sürüngenlerin en tartışmalı grubu olarak ele alınmaktadır. Kaplumbağalar kabaca Mesozoik zamanın Trias döneminin (200-250 MYÖ) sonlarında ortaya çıkmışlardır. Kaplumbağalar ve diğer amniyotlar arasındaki olağanüstü morfolojik değişim, kaplumbağaların Permiyen ve Trias'ta var olan (300 MYÖ) parareptiller olarak bilinen ilkel sürüngenlerden dallandığını ortaya koymaktadır $[7,8]$. Ayrıca çeşitli fosil kayıtlarına göre, kaplumbağaların çoğunlukla karasal orjinli, bazılarının ise sucul orjinli canlı grubu olduğu belirlenmiştir [9].

\subsection{Anapsid-Diapsid Ayrımı}

Kaplumbağaların vücut morfolojilerinin kökeni sürüngen evriminin en önemli gizemlerinden birini oluşturmaktadır. Kaplumbağaların anatomisi, kaplumbağalar ile diğer sürüngen grupları arasındaki ilişkiyi ortaya çıkarmayı zorlaştıracak ölçüde büyük çeşitlilik göstermektedir [9]. Yaşayan kaplumbağalar, anapsid kafatasına sahip (kafatasında temporal açıklığın bulunmaması) sürüngenler olarak değerlendirilmiştir. Anapsid kafatasının morfolojik yapısı diapsid kafatasına sahip (kafatasındaki temporal bölgede 2 adet açıklığın bulunması) sürüngenler ile karşılaştırıldığında daha ilkeldir. Gaffney [10] diapsid sürüngenler ile memelilerin alt temporal açıklı̆g paylaşmalarından dolayı kardeş grup olduklarını, kaplumbağaların da bu iki canlı grubunun oluşturduğu topluluğa yakın akraba olduğunu belirtmiştir.

Zardoya ve Meyer [11] memeliler ile kuşlar arasında kardeş grup ilişkisini öne süren Haematothermia hipotezi ile birlikte kaplumbağaların en basit-yaşayan amniyot grubu olduğu görüşünü reddetmiştir. Ayrıca kaplumbağaların kafatasındaki delikleri ikincil olarak kaybettiklerini ortaya koymuştur. Bir başka ifade ile bu delikler hiç oluşmamasından ziyade sonradan kaybedilmiştir. Temporal açıklığın ikincil olarak kaybını imkânsız kılacak hiçbir güçlü neden olmamasının yanında [12], çeşitli morfolojik kanıtlar, temporal açıklığın ikincil olarak kaybının kabul edilmesi gerektiğini göstermiştir (Ör: Nothosaurs, Plesiosaurs ve Ichthyosaurs gibi nesli tükenen euryapsidler) [12,13]. Son zamanlarda, kapsamlı morfolojik çalışmalar temel alındığında, kaplumbağaların diapsid özelliklere sahip canlılar olduğu görüşü ağır basmaktadır [13-16]. 


\subsection{Kaplumbağa Filogenisi}

Gerçekleştirilen çeşitli moleküler çalışmalar, kaplumbağaların Tuatara, kertenkele ve yılanların dahil olduğu Lepidosauria grubunun dışında yer aldığı ve timsah ile kuşların bulunduğu Archosauria grubuna kardeş grup olduğunu ortaya koymuştur [11,17,18].

Kumazawa ve Nishida [19] kaplumbağaların orijininin sonradan kaybolan iki çift temporal açıklık ile archosauromorph bir atadan geldiğini güçlü istatistiksel testlerle ortaya koymuştur. Ayrıca kaplumbağa soy hattının orijininin, paleontolojik kayıtlardan Benton [14] en az 240 MYÖ meydana geldiği saptanan Aves ve Crocodilia grupları arasında oluşan ayrımdan daha önce, hatta kabaca 260 MYÖ archosauromorph ve lepidosauromorph arasında oluşan ayrımdan da önce oluştuğu saptanmıştır. Buna göre, archosaurian soy hattından kaplumbağaların ayrılmasının en eski kaplumbağa olarak bilinen geç Trias dönemindeki Proganochelys'in ortaya çıkışından biraz daha önce Permiyen döneminden geç Trias'a kadar olan bir zaman dilimi içerisinde meydana geldiği belirlenmiştir [19].

Protein sekansları (LDH-A, LDH-B ve $\alpha$-enolaz) kullanılarak yapılan çalışmalarda timsahların kaplumbağalara en yakın canlı grubu olduğu belirlenmiştir [15,20,21]. Bu filogeni büyük oranda, Captorhinidler veya Pareiasaurus olarak adlandırılan kaplumbağaların, en yakınları arasında gösterilen, soyu tükenen Paleozoik anapsidlerin ilkel karakterleri olan temporal açıklıklarının olmamasına bağlıdır [19]. Liao vd. [15] kaplumbağaların timsahlardan 177 MYÖ, Trionychidlerin ise diğer kaplumbağalardan 100 MYÖ ayrıldığını tespit etmişlerdir.

Gerek fosil temelli [14] gerekse diğer moleküler tekniklere [22] dayanarak yapılan çalışmalarda, büyük tetrapod gruplarının evrimsel süreçte birbirlerinden ayrılma zamanları için aşağıdaki diyagram ortaya konmuştur (Şekil 1).

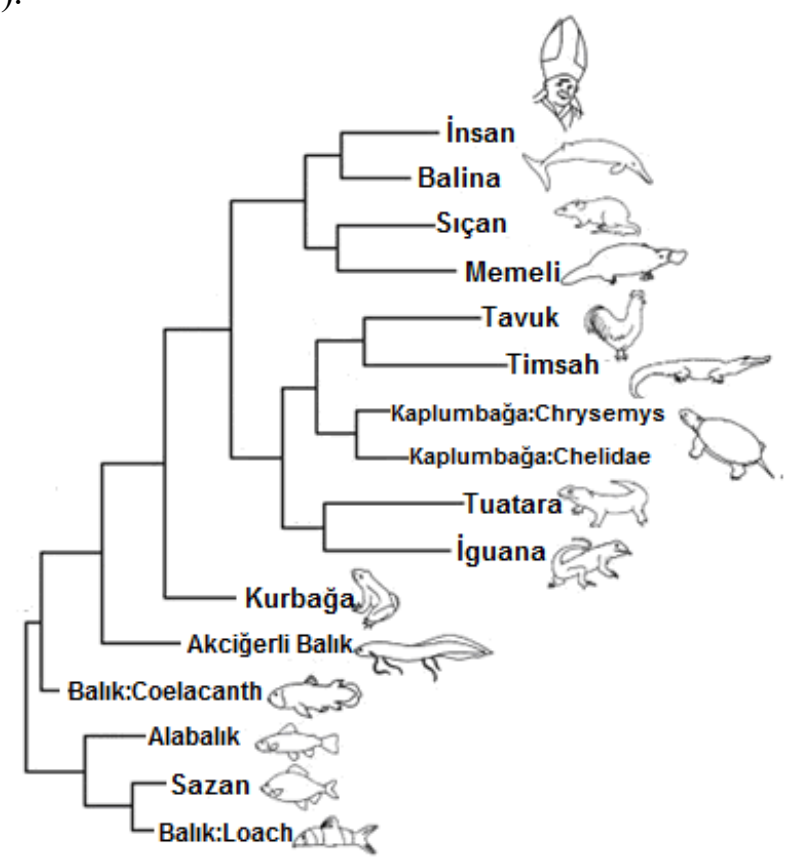

Şekil 1. mtDNA’ya göre canlı grupları arasındaki filogenetik ilişki [11]

Buna göre, timsah-kaplumbağa ayrımının günümüzden 151.6-23.7 MYÖ gerçekleştiği tahmin edilmektedir [11]. Laurin ve Reisz [7] en eski kaplumbağanın fosil kaydı ve moleküler tahmin ile kaplumbağaların 100 MYÖ çeşitlendiğini belirtmiştir. Gaffney [23] fosil kayıtlara göre, en eski kaplumbağanın son Triasik dönemde (en az 200 MYÖ) yaşamış olan Proganochelys olduğunu tespit etmiştir. Bu iki çalışma arasındaki 100 MY'lık fark parareptillerin kaplumbağalara en yakın grup olup olmadığı hususundaki tartışmadan kaynaklanmaktadır [24,25]. Bu nedenle, günümüz çalışmalarında kaplumbağalar, diapsidlerle ilgili karşılaştırmalı çalışmalarda ideal bir dış grup olarak kullanılmaktadır. Mannen ve Li [21] karşılaştırmalı morfolojistlerin, kaplumbağaların filogenetik durumları tamamıyla çözülene kadar diapsidler içinde bir dış grup olarak kullanılmaları hakkında daha dikkatli olmaları gerektiğini ifade etmiştir.

Geç Trias döneminden en eski kaplumbağa olarak bilinen Proganochelys'e ait kanıtlar onun kökeni hakkında bir ipucu vermemektedir. Li vd. [9] günümüzden 220 MYÖ’ne ait olan ve nispeten 
Proganochelys'ten daha eski bir geçmişe sahip Odontochelyidae isimli yeni bir familya tanımlamışlardır. Daha sonra, Çin'de Odontochelys'ten çok daha büyük Eorhynchochelys sinensis isimli günümüzden yaklaşık 228 MYÖ yaşadığı belirlenen yeni bir fosil tür kaydı tespit edilmiştir (Şekil 2). Söz konusu çalışmaya göre, bilinen bütün kaplumbağa ve fosillerinin en eskisi $E$. sinensis olarak tespit edilmiştir [16].

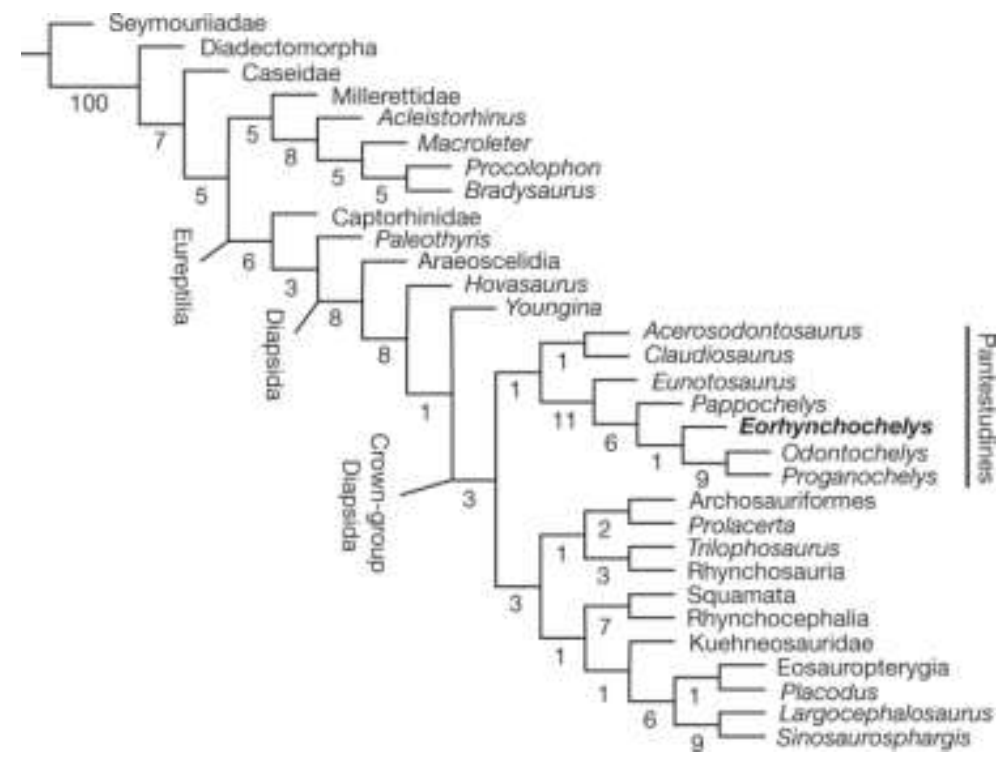

Şekil 2. Amniyotlar arasındaki Eorhynchochelys' in filogenetik durumu [16].

Barley vd. [24] kaplumbağa familyaları arasında evrimsel ilişkiyi ortaya koymuştur (Şekil 3). Buna göre; Carettochelyidae ve Trionychidae familyalarını içeren Trionychia grubunun Pleurodiralardan ayrılmasından sonra diğer kaplumbağa familyalarının evrimleştiği tespit edilmiştir.

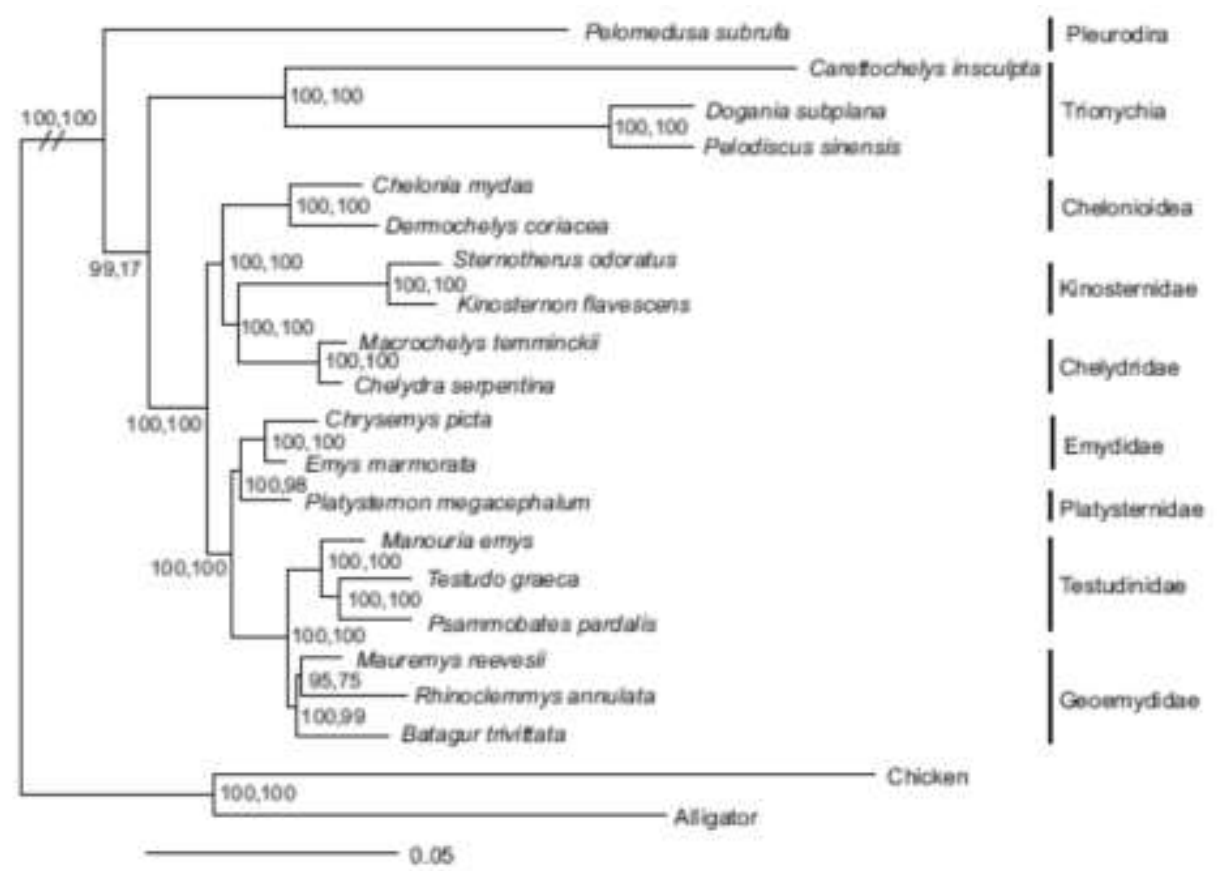

Şekil 3. Kaplumbağa familyaları arasındaki filogenetik ilişkiyi gösteren ağaç [24].

\section{Trionychidlerin Evrimsel Gelişimi}

Trionychidae familyası günümüzde 250 türden daha fazlasını içermektedir (geç mezozoikten günümüze kadar yaşamış 230 fosil kayıt ve 13 cinse ait 31 mevcut tür). Antarktika kıtası hariç diğer bütün kıtalarda 
yayılış göstermektedir [25]. Kratese jeolojik döneminin başlarında Asya'dan orjinlenen Trionychidae familyası Kratese'nin sonlarında Kuzey Amerika'dan ayrılmış ve Tersiyer'de Antarktika kıtası haricinde tüm kıtalarda yayılış göstermiştir [26-29].

\subsection{Morfolojik ve Osteolojik Özelliklerine Göre Evrimsel Durumu}

Yumuşak kabuklu kaplumbağalar (Trionychidae) Asya kıtasının Kratase jeolojik döneminin başlangıcından (yaklaşık 100-140 MYÖ) günümüze kadar gelen, yüksek oranda morfolojik çeşitlilik gösteren kaplumbağaların eski bir grubudur [30]. Trionychid kabuğu diğer kaplumbağalarla kıyaslandığında dorsoventral yönde yassılaşmış ve üzeri kemikleşmiş plak tabakanın yerine deri bir tabakayla örtülmüştür. Boyunları uzun ve içeri çekilebilme özelliğindedir. Ön ve arka üyelerinin her biri 3 adet uzun tırnak bulundururlar ve suda yüzmek için pedal gibi kullanırlar. Esnek olan karapas kenarları trionchidlerin çamurlu çevrelere iyi adapte olmasını sağlamıştır. Esnek yapıdaki bu karapas kenarları sayesinde, nehir, göl veya deniz ekosistemlerinin dip sedimentlerini dalgalandırma hareketi ile kazarak korunma amaçlı kendilerini kamufle ederler [31].

Trionychidler tipik olarak uzayan bir boyun ve uzun bir burun yapisina sahiptirler. $\mathrm{Bu}$ özelliklerini çamurda gizlenmiş halde bulunduğu sırada avına saldırma veya nefes almak için su yüzeyine ulaşmak amacıyla kullanırlar. Günümüzde var olan bütün Trionychidlerin büyük oranda sucul ortamda yaşarlar ve çoğu balıkların önemli predatörleri konumundadır. Dış morfolojileri değişkenlik göstermesinden dolayı taksonomik ve filogenetik amaçlar için kullanmak son derece zordur. Bunun yerine tür veya gruplar arasındaki ayrımı sağlamak için genellikle osteolojik karakterler kullanılır [1,3234].

Trionychidae familyasına ait kaplumbağalar, diğer kaplumbağaların çoğunda karakteristik olan karapas plaklarının kaybı, kabuk kemik elementlerinin azalması gibi özelliklere sahiptirler. Coğrafik olarak geniş bir alanda yayılış gösteren bu familya üyeleri, eski ve morfolojik olarak diğer kaplumbağalardan farklı tuhaf görünüşte olan kaplumbağalardır. Trionychidlerde var olan düz vücut yapısı, bu canlıların yaşam alanı konumundaki su, kum veya bataklık alanların oluşturduğu harekete karşı direnci azaltır. Bununla birlikte trionychidlerde vücudu çevreleyen peripheral kemiklerin kaybolmasından dolayı toplam karapas ağırlığı ile birlikte tüm vücut ağırlığında dikkate değer bir azalma meydana gelmiştir [35]. Peripheral ve neural kemiklerin sayısındaki düşüş ile birlikte 7. pleural ve nukal kemiğin büyüklüğündeki azalmadan dolayı trionychid kabuğunda bir ağırlık kaybı söz konusudur. Ayrıca bu durum, kaplumbağanın sudaki hareketi esnasında, kabuğun su direncini azaltmak üzere özelleşmiş bir şekil almasını sağlamıştır. Bu gruba giren kaplumbağalar, karapaslarında yer alan kemik plaklarında bir azalma olmasına rağmen, geçmişte yayılış alanlarının büyük bir çoğunluğunda kaplumbağa yiyen timsahlarla bir arada yaşamışlardır. Meylan [1] trionychidlerin bu koşullar altında hayatta kalmasını predatörlerden saklanabilme ve hızlı yüzebilme yeteneklerine bağlamıştır. Kaplumbağalar arasında en hızlı yüzen türlerin bazıları trionychid grubunda yer almaktadır [36]. Özelleşmiş kabukları, balık ve diğer yüzen avlara karşı hızlı predatör saldırı yapmaları için de avantaj sağlar [37].

\subsection{Fosil Kayıtlara Göre Evrimsel Durumu}

Trionychidae familyasında yer alan kaplumbağalardan bazıları, Dünya'da yayılış gösteren en büyük kaplumbağalardandır [38]. Ayrıca bu familyaya mensup çoğu kaplumbağa, IUCN Kırmızı Listesi'ne göre "nesli tükenmeye başlayan" hayvanlar grubundadır [39]. Mevcut Trionychidler Kuzey Amerika, Avrupa, Afrika, Asya ve Doğu Hindistan olmak üzere çok geniş bir dağılış sahasına sahip [40] olmaları yanında Avustralya'dan da fosil kayitları mevcuttur [41]. Hutchinson [37] Kuzey Batı Amerika'dan elde ettiği fosil kayıtlara göre Trionychidae'nin Senozoik devirde yaşayan 11 sürüngen familyasından biri olduğunu tespit etmiştir.

Trionychidlerin evrimsel süreçte meydana gelen karakter değişimlerinin nedenlerini açıklayan birçok olasılık mevcuttur:

(1) Büyük oranda ağzı ile avını yakalamak için seçilim

(2) Çok hızlı bir şekilde yüzebilme için seçilim

(3) Büyük oranda kazmaya uygun üye için seçilim [35]. 
Trionychidlerin Carettochelyidlerden evrimleştĭgini gösteren önemli evrimsel olay peripherallerin kaybıdır (Lissemys cinsi hariç). Söz konusu durum, vertebral orta hatta kaburga başlarının çok ince ve geniş sütur oluşturmasıdır. Büyük kaburga başlarının gelişimi, plastronun (peripheraller yoluyla) kullanımına yapısal bir alternatif oluşturur. Sonuç olarak Trionychid kabuğu pedamorfik olabilir; yani embriyonik dönemde karapas gelişimindeki son adım asla meydana gelmez. Pedamorfizmin, trionychidlerin kabuklarının evrimleşmesini sağlayan mekanizma olabileceği düşünülmektedir [1].

Trionychidlerin fosil kayıtları oldukça yaygındır ve geç Kretase döneminden bazı fosil taksonlar içermesi nedeniyle modern cins içinde sınıflandırılmıştır [42]. Bu fosil kayıt ve taksonun yüksek miktarda apomorfik morfolojik karakterlere sahip olması, bu grubun evrimsel olarak eski olabileceğini ortaya koymaktadır [43]. Fosil kayıtlardan Trionychidlerin Paleojen döneminde Avrupa'da bulunduğu ve Pliosen/Pleistosen'e kadar da Avrupa'nın önemli sürüngenleri içerisinde yer aldığ 1 tespit edilmiştir [44,45]. Bununla birlikte, Trionychidae familyasının ilk evrimine ilişkin 2 olasılık bulunmaktadır [46]. Bunlardan ilki temel Trionychid ayrımı Asya'da meydana gelmiş olmas1, ikincisi ise Trionychid'lerin Kuzey Amerika'ya ayrı bir soy hattı olarak geçişinden sonra meydana gelen vikaryans olayı ile ayrım gerçekleşmiş olmasıdır.

Pritchard [35] Chitra'nın atasal Trionychidler için en iyi model olduğunu ve Trionychidlerin vücut yapısının hızlı predatör saldırısı için meydana gelen bir adaptasyon olduğunu öne sürmüştür. Buna kanıt olarakta, Chitra ile Avrupa'da Jura veya Kretase döneminde yaşamış olan Chitracephalus dumonii [47] kafataslarının benzerliklerini göstermiştir. Ayrıca Chitra'nın trionychidler arasında en iyi gelişen etçil hayvan olduğunu ve diğer formların ikincil olarak oluştuğunu ortaya koymuştur. Mustoe ve Girouard [37] Kuzeybatı Washington/ABD'de Tersiyer döneminin başlangıcından kalmış, Trionychidae familyasına ait olduğunu belirledikleri bir fosil tespit etmiştir.

\subsection{Trionychidae Filogenisi}

Diğer kaplumbağalarla Trionychidae familyasındaki kaplumbağaların akrabalığı her zaman tartışma konusu olmuştur. Bazı araştırıcılar bu familyanın Cryptodira ve Pleurodira dışında ayrı bir alttakım altında sınıflandırılması gerektiğini belirtmişlerdir [48-50]. Bazı morfologlar ise, bu familyanın Carettochelyidae, Dermatemydidae ve Kinosternidae familyalarına akraba olan bir grup olduğunu öne sürmüşlerdir [10,51,52]. Carettochelys grubu belirlendiğinden beri araştırıcılar, bu cinsi Trionychidlere en yakın grup olarak kabul etmişlerdir [48,53]. Carettochelys ve Trionychidae arasındaki yakın akrabalığı tanımayan araştırıcılar arasında bazıları, bu iki grubu bir süperfamilya altında birleştirmişlerdir (Trionychia olarak Joyce vd. [54], Trionychoidea olarak Shaffer vd. [55]. Son moleküler çalışmalar ise Carettochelys insculpta (Avustralya/Yeni Gine domuz burunlu kaplumbağa) ile Trionychidlerin kardeş gruplar olarak ortaya koymakta [55-57] olup, bu iki grubun oluşturduğu dal, yaşayan diğer tüm Cryptodirlerin ve yaşayan diğer bütün kaplumbağaların kardeş grup olarak göstermektedir. Moleküler veriler ve fosil kayıtlar Trionychia ve diğer tüm kaplumbağalar arasındaki ayrımın günümüzden yaklaşık olarak 90-120 MYÖ gerçekleştiğini ortaya koymaktadır [55].

Bazı morfolojistler, Carettochelyidae ve Trionychidae ile Dermatemydidae ve Kinosternidae gruplarını birlikte değerlendirmişlerdir [10,51,52,58,59]. Gaffney [10] bu 4 familyayı Trionychoidea süperfamilyası altında birleştirmiştir. Trionychidae familyası içindeki akrabalık ilişkilerini ortaya koyan temel bilgi, Meylan [1]'nın kafatası, kabuk ve postkranial iskelet temelli morfolojik karakterlerin analizine dayanmaktadır. Meylan [1] bu çalışmada, 4 familyanın monofiletik bir grup olduğu hipotezini desteklemiş ve bu monofili durumunu 9 osteolojik karaktere dayanarak ortaya koymuştur. Osteolojik verilere göre, Dermetemydidae familyası diğer 3 familyaya kardeş grup olarak ortaya konmaktadır [1]. Trionychidae familyası monofiletik değildir. Sistematik çalışmalar [1,10,52] familyayı monofiletik bir grup olarak tanımlarken, Meylan [1] osteolojik verilere dayanarak bunun mümkün olmadığını tespit etmiştir.

Meylan [1] Flap-Shelled (Dudakl1) kaplumbağaları Cyclanorbinae olarak ayrı bir altfamilyaya ayırmıştır. Geri kalan Trionychidae familyasındaki kaplumbağalar ise Trionychinae altfamilyasına dahil edilmiş̧ir. Dudaklı kaplumbağalarda monofili söz konusudur [60]. Ayrıca Meylan [1] Cyclanorbinae için 12, Trionychinae için ise 9 adet paylaşılan morfolojik karakter belirlemiş ve bu iki alt familyanın kuvvetli bir şekilde reziprokal monofili olduklarını ortaya koymuştur. 
Meylan [1] Trionychinae altfamilyasını 4 gruba ayırmış ve bu altfamilyanın monofiletik olduğunu öne sürmüştür. Bu gruplar;

1-Üç eski dünya türünü (Trionyx triunguis, T. euphraticus ve T. swinhoei) ve üç Kuzey Amerika formunu (T. ferox, T. muticus ve T. spiniferus) içeren Kuzey Amerika grubu,

2-Hindistan grubu; T. gangeticus, T. leithii, T. hurum ve T. nigricans

3-Trionyx steindachneri grubu; T. steindachneri, T. sinensis ve T. subplanus

4-Trionyx cartilagineus grubu; T. cartilagineus, Chitra indica ve Pelochelys bibroni.

Hummel [61] tarafından gerçekleştirilen revizyondan Meylan [1]'e kadar olan dönemde Trionychidae familyasına mensup bireyler (Chitra ve Pelochelys dışındaki), Trionyx isimli tek bir cinste toplanmaktayd. Meylan [1] kladistik sinıflandırma ile önceleri sadece Trionyx cinsi içinde yer alan türleri 9 cins ve 15 türe ayırmıştır (Şekil 1.4). Meylan [1] böylece Trionychidae içindeki cins sayısını 3 'ten 11'e yükseltmiştir. Meylan [1] bu 11 cinsi 4 tribusun içinde gruplandırmıştır. Bu tribuslar: Chitrini, Aspideretini, Trionychini ve Pelodiscini. Bu dört dalın her birinin monofili durumunu çok iyi bir şekilde ortaya koymasına rağmen, tribuslar arasındaki akrabalığı çözememiştir.

Engstrom vd. [43] Trionychinae ve Cyclonorbinae altfamilyaları arasında monofili olduğunu belirlemiştir (Şekil 4). Gerçekleştirdikleri analizler sonucunda, Meylan [1]'nın aksine, Chitrini, Pelodiscini ve Trionychini tribuslarının monofili durumunu kabul etmemektedirler. Bunun nedeni olarak ta, Meylan [1]'de, özellikle Chitrini ve Trionychini tribuslarının herbirinde birer taksonun hatalı bir şekilde sınıflandırılması olarak ortaya koymuşlardır. Sadece Aspideretini tribusunun monofiletik olduğu belirlenmiştir. Trionychidae içerisinde ayrılan iki dal, Trionychinae ve Cyclanorbinae, hem Meylan'nın morfolojik verileri hem de Engstrom [43]'ün moleküler verileri tarafından desteklenmiştir.

Meylan [1]'a kadar olan hiçbir çalışmada T. triunguis Kuzey Amerika grubuna dâhil edilmemiştir. Loveridge ve Williams [62] T. triunguis' 'i, T. sinensis ve T. steindachneri ile birlikte Kuzey Amerika grubuna kardeş grup olarak göstermiştir. deBroin [60], T. triunguis'i, Kuzey Amerika formları evrimleşirken onlardan bağımsız olarak ayrılıp evrimleşen kalıntı bir grup olarak göstermiştir. Meylan [1] osteolojik verileri temel aldığında K. Amerika grubu'nun en iyi kardeş grubu olarak T. triunguis'i belirlemiştir. Trionyx triunguis, Trionyx cinsinin tip türü olması açısından taksonomik olarak oldukça önemlidir.

Engstrom vd. [63] Chitra cinsine ait kaplumbağaların mitokondrial DNA'nın ND4 gen bölgesini kullanarak yaptıkları filogenetik analizler sonucunda Chitra chitra ve $C$. indica türlerinin birbirlerinden önemli derecede ayrım gösterdiğini, bununla birlikte Myanmar' dan elde edilen örneklerin bu iki türden ayrı bir tür olarak ele alınması gerekliliği ortaya koymuştur.

Engstrom vd. [43] genellikle nehir ağızlarında yaşayan Trionyx, Pelochelys ve Chitra cinslerinin aynı dalda yer aldıklarını tespit etmiştir (Şekil 5). Bu grup, yaşayan Trionychidlerin en eski atasal grubu olabilir. Bu dalın günümüze kadar neslini devam ettiren tüm üyeleri, yetişkinlerinin oldukça büyük vücut büyüklüğüne sahip olması, yani genellikle karapas uzunluğunun $100 \mathrm{~cm}$.yi aşması ve sık sık denizel habitatları veya nehirlerin denize dökülen bölümlerini kullanması ile karakterize edilmektedir [64]. Engstrom vd. [43] bu özelliklere paralel olarak Trionyx, Pelochelys ve Chitra'nın oluşturduğu dala "Gigantaestuarochelys" adını vermişlerdir. Ayrıca Chitra ve Pelochelys' in oluşturduğu Meylan [1]'nin Chitrini olarak isimlendirdiği dal da "Chitraina" olarak isimlendirilmiştir. Trionychidae familyasına ait 5 tane monotipik cins (Amyda, Dogania, Palea, Pelodiscus ve Trionyx) yer almaktadır. Engstrom vd. [43] bunlardan, Amyda cartilaginea, Dogania subplana, Palea steindachneri ve Peladiscus sinensis ile birlikte Aspideretini tribusunun yakın akraba olduğunu tespit etmiş ve bu taksonların oluşturduğu dala yeni bir isim olarak "Amydona", Meylan [1] tarafından Trionychini olarak belirtilen Apalone ve Rafetus cinslerinin oluşturduğu dala ise "Apalonina" adını vermiştir. Bununla birlikte, Amydona ve Apalonina'nın birlikte oluşturdukları grup Gigantaestuarochelys'e en yakın grup olarak ortaya konmuştur (Şekil 5).

Praschag vd. [34] mtDNA sitokrom b geninde gerçekleştirdikleri moleküler filogeni çalışmasında Trionychidae familyasında yer alan ve önceleri Nilssonia cinsi ile aralarında parafili durumu söz konusu olan [43] Aspideretes cinsine giren 4 türü (Aspideretes gangeticus, A. hurum, A. leithii, A. nigricans) Nilssonia cinsine dâhil etmiştir.

Son olarak Li vd. [65] gerçekleştirdikleri çalışmada Trionychidae familyasının Carettochelyidae'ye en yakın takson olduğunu ortaya koymuştur. Bununla birlikte, filogenetik analizlere göre, Trionchidae familyası yaklaşık 108 MYÖ Asya'da ortaya çıkmış, bundan sonraki ayrımlar ise temel olarak iki sıcak dönemde (geç Kretase-Erken Eosin ve Oligosen) ve üç farklı rota 
izlenmesiyle meydana gelmiştir. Bununla birlikte, bu ayrım zamanları Bering Boğazı'nın açılması ve Hindistan-Asya çarpışma zamanları ile uyumluluk göstermektedir.

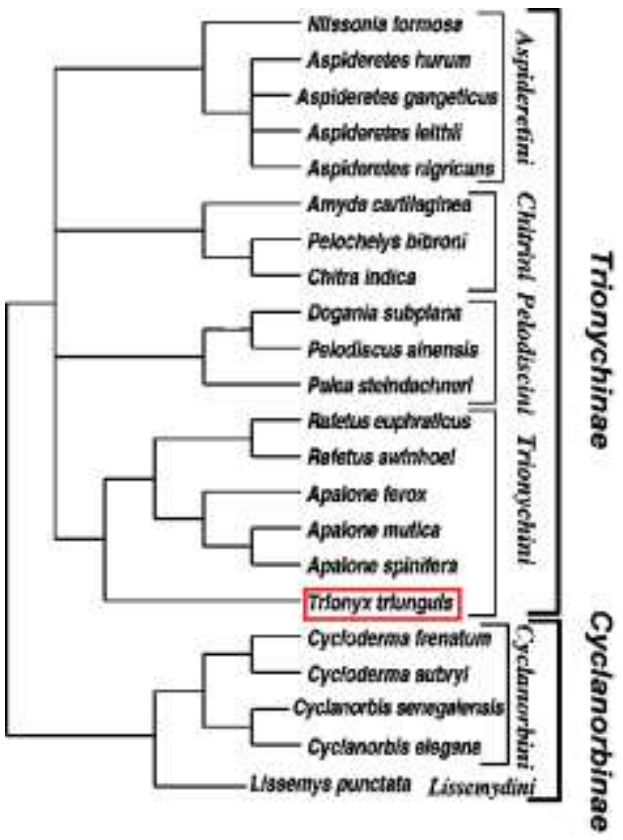

Şekil 4. Osteolojik karakterlere göre Trionychidae familyasına ait türler arasındaki akrabalık ilişkisi [1]

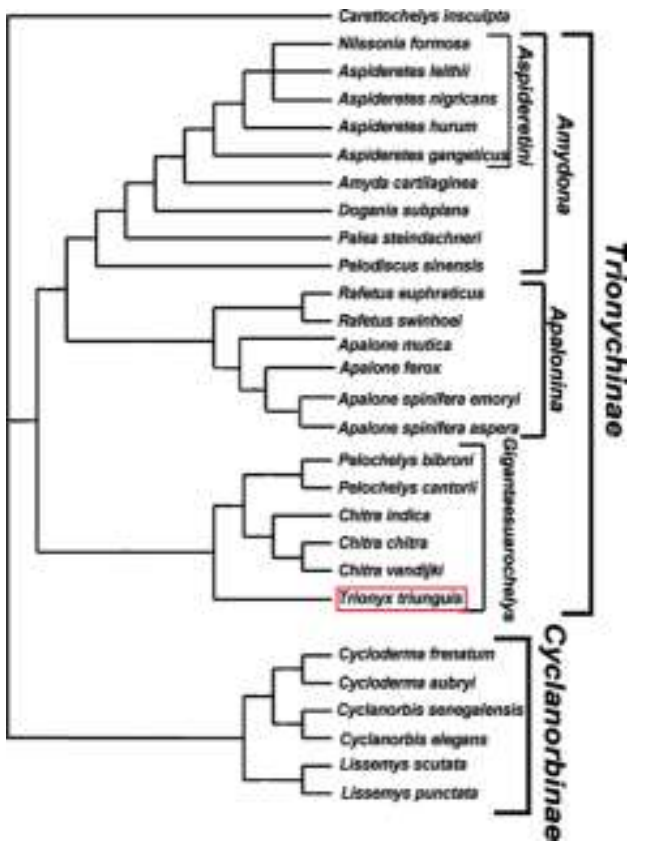

Şekil 5. Çekirdek ve mtDNA verilerine göre Trionychidae familyasına ait türler arasındaki akrabalık ilişkisi [43]

\subsection{Trionyx triunguis Forskål, 1775 (Nil Yumuşak Kabuklu Kaplumbağası)}

Habitat: Göllerde, havuzlarda ve nehirlerin sığ kısımlarında yaşayan tamamıyla sucul özelliklere sahip canlılardır. Yumurta bırakma işlemini küçük kum tepelerinin vejetasyon olan kesimlerindeki bitki köklerine yakın bölümlerde gerçekleştirirler (Şekil 6). Şekil 6'da Nil yumuşak kabuklu kaplumbağası'nın fotoğrafi bulunmaktadır. Trionyx triunguis genellikle hafif tuzlu suların bataklık bölümlerinde yaşadıkları bilinmelerine rağmen özellikle kış aylarında denizlerde türe ait çok sayıda kayıt tespit edilmiştir [66-68]. Bu durum, yaşam döngülerinin bir kısmını denizel ortamlarda geçirdiğinin bir göstergesidir. Trionyx triunguis' in tuzlu suya olan geniş duyarlılık yeteneği, bu türe güneydoğu Akdeniz ve Avrupa'nın güneydoğusunda koloni oluşturabilme imkânı tanımıştır [69].

Yayılışı: Trionyx triunguis günümüzde Türkiye'nin Akdeniz kıyıları ile birlikte Moritanya ve kuzey Namibya'dan Somali ve Mısır'a kadar olan bölümde yayılış göstermektedir.

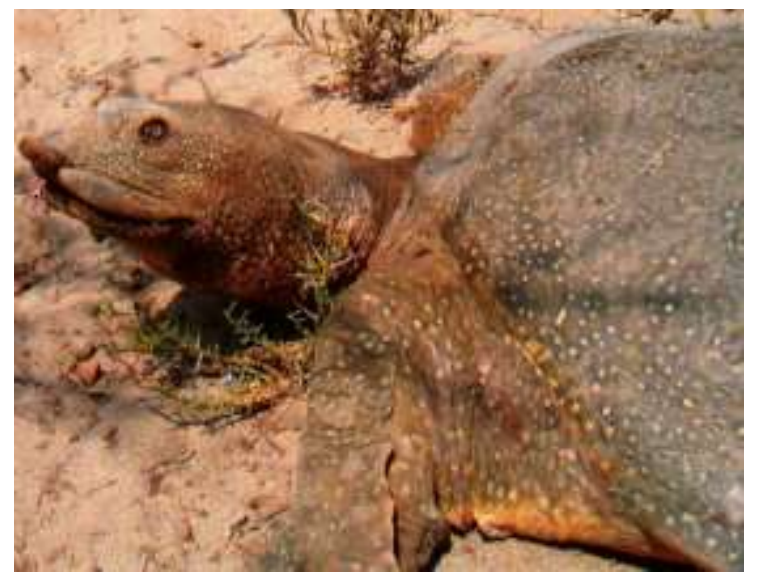

Şekil 6. Nil yumuşak kabuklu kaplumbağası

Güney Afrika dışında Afrika kıtasının büyük çoğunluğuna dağılmıştır: Kongo ve Batı Afrika'daki su kanalları, Mısır (Nil Nehri dışında), Eritrea, Etiyopya, Sudan, Güney Somali ve Kenya [70], Angola, Benin, Çat, Fildişi Sahilleri, Namibya'nın kuzeyi ve Senegal'in batıs1, Mali [71], Gabon, 
Gambia, Kamerun, Gana, Gine, Moritanya, Nijer, Nijerya, Raunda [72], Sierra-Leone, Suriye, Togo ve Uganda. Suriye, Lübnan, İsrail ve Türkiye, T. triunguis'in Akdeniz'deki en önemli yuvalama alanlarıdır [Şekil 7) [73-75].

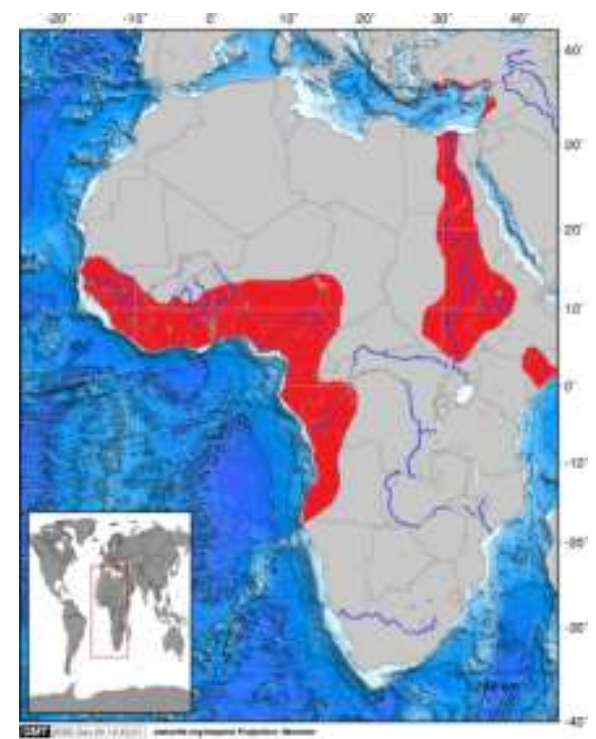

Şekil 7. T. triunguis'in Dünyadaki yayılış sahası

Populasyon büyüklüğünü belirlemek için ayrıntılı bir çalışma olmamasına rağmen Akdeniz populasyonunun 1.000 bireyden daha az olduğu tahmin edilmektedir [74]. MEDASSET'in 2002 yllinda Nil Nehri'nde gerçekleştirdiği araştırmada türün bu bölgede son 20 yıldır görülmediği tespit edilmiştir [73]. Buna göre, T. triunguis'in Mısır'da soyunun tükendiği düşünülmektedir [74]. Ancak Amer ve Kumazawa [76] gerçekleştirdikleri moleküler çalışmada bu türe ait örnekleri Nil Nehri'nin batı bölümünde yer alan Nasser Gölü'nden elde etmişlerdir. Ayrıca Türkiye'den ilk ve tek fosil kaydı Tuna [77] tarafından Bayraktepe/Çanakkale/Türkiye'den verilmiştir.

MEDASSET'in 1997 yılından beri Türkiye'de gerçekleştirdiği çalışmalar, Çukurova ve Dalaman deltalarının türün Akdeniz'deki önemli yuvalama alanları olduğunu göstermiştir [67]. Türkiye' de türün yuvalama yaptığı 16 alan belirlenmiştir (Şekil 8).

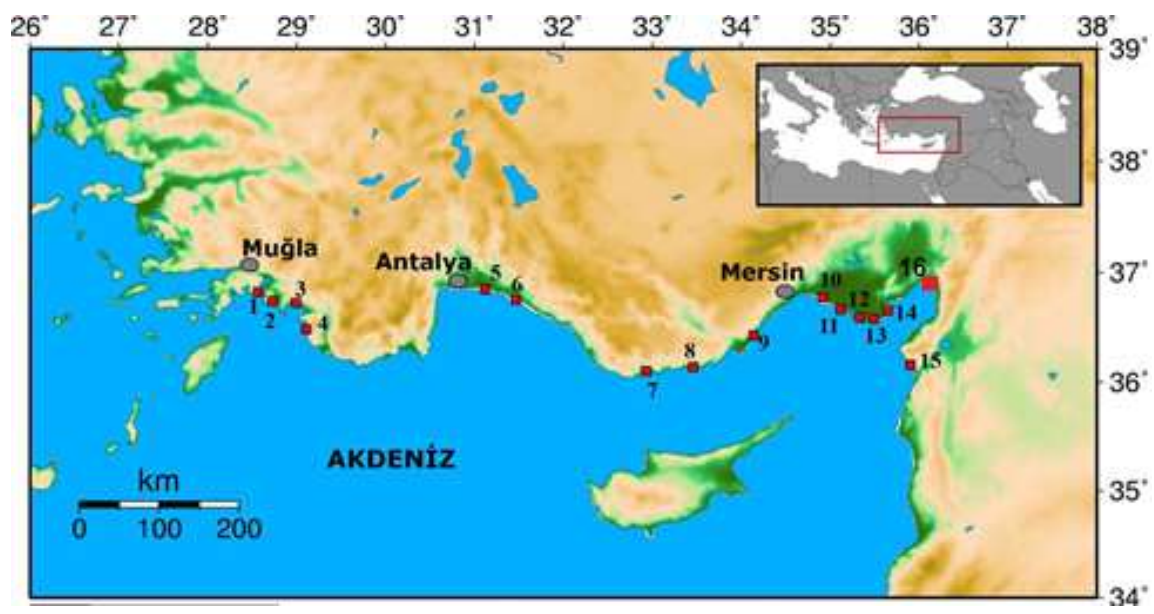

Şekil 8. T. triunguis 'in Türkiye'deki yayılışı [67,78]:1.Dalyan, 2.Dalaman, 3.Fethiye, 4.Patara, 5.Aksu Nehri, 6.Köprü Çayı, 7.Anamur, 8.Bozyazı, 9.Göksu Nehri, 10.Berdan Nehri, 11.Seyhan Nehri, 12.Tuzla drenaj kanal1, 13.Karataş drenaj kanal1, 14.Ceyhan Nehri, 15.Asi Nehri, 16. Burnaz 
Davranış: Trionychidler, avlanmak için genellikle suyun kumlu veya killi dip kısımlarında saklanarak yaşarlar. Uzun bir boyun ve buruna sahip olmaları suyun yüzeyine çıktıklarında nefes almaları için kolaylık sağlar. Nil yumuşak kabuklu kaplumbağa akciğer, farinks, deri ve kloak solunumu yapabilir. Suyun içinde veya karada çok hızlı hareket edip yönlerini seri bir şekilde değiştirme yeteneğine sahiptirler[79,80].

Üreme: Dişi T. triunguis yaklaşık 100 pin-pon topu büyüklüğündeki yumurtayı aynı anda depolayabilir fakat bunların genellikle ancak 50 tanesini yumurtlar [80]. Gidiş ve Kaska [81]Dalaman bölgesinde yer alan T. triunguis için inkübasyon süresini 55-56 gün olarak tespit etmiştir. Türkiye'de üç farklı kumsalda elde edilen verilere göre ortalama kuluçka büyüklüğü 34 yumurtadır [78]. Trionychidlerde genotipik cinsiyet tayini söz konusudur. Yani, cinsiyet oranı, koruma önlemlerinin bir parçası olarak yapay sıcaklık değişimleri uygulanarak değiştirilemez, cinsiyet tayini sıcaklığa bağlı değildir [80,82].

Beslenme: Nil yumuşak kabuklu kaplumbağası karnivor olmakla birlikte besinlerinin büyük çoğunluğunu balıklar ve gastropodlar oluşturmaktadır. Bunların yanında sucul böcekler, krustaseler, kurbağa, kertenkele ve çeşitli bitkisel besinler de önemli besin kaynağıdır.

Tehditler: T. triunguis'in çok geniş dağılışına rağmen Akdeniz populasyonu yoğun balıkçıllık aktiviteleri, sulama aktiviteleri yüzünden habitatların yoğun kullanımı, insan etkisi, su kirliliği, yuvalama alanlarının yok edilmesi ve teknelerin yol açtığı tahribat gibi nedenlerden dolayı büyük ölçüde tehdit altındadır [83,84]. Trol balıkçılığı bu türü tehdit eden en önemli tehlikelerden biridir. $\mathrm{Bu}$ kaplumbağalar hayat döngülerinin önemli bir kısmını denizlerde geçirirler [67,68]. 1980'li yılların ortalarında Dalyan/Dalaman bölgesindeki turizm aktivitesindeki yoğun artış Nil yumuşak kabuklu kaplumbağa populasyonunu yüksek oranda tehdit etmeye başlamıştır. Habitat yıkımı, tekne trafiğgi ve su kirliliği gibi etmenler bütün populasyonların uzun vadede hayatta kalma olasıllğı için büyük bir tehlike oluşturmaktadır. Bunun yanında, türün yırtıcı özelliğinden dolayı balık ağlarını parçaladığı için balıkçılar tarafindan öldürülmektedir [74].

\section{Sonuç}

Trionyx triunguis Bern Sözleşmesi'ne (Convention on the Conservation of Europen Wildlife and Natural Habitats) göre Ek II: "Kesinlikle korunması gereken fauna türleri” kapsamındadır. Trionyx triunguis' in global dağılışı göz önüne alındığında bu tür, IUCN (International Union for Conservation of Nature)'in “Tehdit altındaki türler" listesinde "Duyarlı" (vulnerable) statüsünde değerlendirilmektedir. Trionyx triunguis'in Akdeniz populasyonunun koruma statüsü "Nesli kritik derecede tehlike altında" (Critically endangered) olarak belirlenmiştir. Kasparek [67] türün ergin birey sayısında giderek azalan bir durum söz konusu olduğunu ve bununla birlikte populasyondaki birey sayısının 1.000 bireyin altına düştügünü belirtmiştir. Ayrıca, Kasperek [67] Türkiye'de türün yuvalama yaptığı alanlardaki balıkçılarla, yerel halk ile görüşmesi neticesinde aldığ 1 bilgiler 1şığında populasyonları büyüklüklerine ve koruma önceliklerine göre Türkiye' de 3 kategori oluşturmuştur (Şekil 8). Bunlar;

I. Kategori: Dalaman ve Seyhan; en büyük ve en yüksek koruma öncelikli populasyon,

II Kategori: Dalyan, Aksu/Acısu, Anamur, Göksu, Berdan çayı, Tuzla Direnaj kanalı, Karataş direnaj kanal1, Ceyhan ırmağ1; göreceli olarak büyük populasyona sahip fakat yüksek koruma önceliği yoktur.

III. Kategori: Patara, Fethiye, Köprü Çayı/Acısu, Bozyazı, Asi Irmağı; küçük populasyona sahip ve türün hayatta kalması için koruma gereklidir.

Bir populasyondaki birey azalması türün genetik çeşitliliğinde güçlü bir kayba neden olmaktadır. Genetik havuzun zengin olması çevresel ve iklimsel şartlara türün daha iyi adaptasyonunu ve türün yaşamasını mümkün kılar [85]. Türkiye' de Nil yumuşak kabuklu kaplumbağası tam anlamıyla koruma altına alınmıştır. 2001 yılında MEDASSET Dalyan populasyonunu Sınıf 2 (Korunması kuvvetle gerekli büyük populasyon) olarak sınıflandırmıştır [86]. Akçınar ve Taşkavak [87] populasyon çalışmasında türün koruma statüsünün "Nesli kritik derecede tehlike altında" (Critically endangered)'dan "Duyarlı" (vulnerable)' ya düşürülmesini önermiştir. Ancak, Güçlü ve Bozdoğan [88] bu tür üzerine yapılan en son çalışmada Türkiye'deki yuvalama kumsallarından elde ettiği örnekler üzerinde moleküler analizler gerçekleştirmiş ve türün genetik çeşitliliğinin oldukça düşük olduğunu ve buna bağlı olarak ta koruma statüsünün "Nesli kritik derecede tehlike altında" olarak kalması gerektiğini ortaya koymuştur. Günümüze kadar, türün Akdeniz havzasında yaşayan populasyonları üzerinde moleküler yöntemler kullanılarak gerçekleştirilen başka çalışmalar da mevcuttur [89-93]. 
Trionyx triunguis türü diğer kara, deniz ve tatlı su kaplumbağalarından farklı olarak deniz, acı ve tatlı su gibi çeşitli ekolojik şartlara çok iyi uyum gösteren oldukça yırtıcı davranışlara sahip bir canlıdır. Yüzey alanı büyük olan karapasın su içindeki hareketi basitleştirecek şekilde diğer türlerden daha yassı olması ve tehlikelerden korunmak, üreme ve beslenme faaliyetlerini kolaylaştırmak üzere uzun tırnak ile güçlü çene yapısına sahip olması ülkemizde yaşayan diğer kaplumbağalara kıyasla çevresel şartlara uyum için avantaj sağladığını göstermektedir. Bu bilgiler, günümüze kadar elde edilen moleküler verilerle birlikte değerlendirildiğinde T. triunguis'in ülkemizde yaşayan en eski kaplumbağa türü olduğu ve korunması için gerekli yönetim planlarının belirlenmesi gerekliliğini ortaya çıkarmaktadır.

\section{Kaynaklar}

[1] Meylan P.A. 1987. The phylogenetic relationships of soft-shelled turtles (Family Trionychidae). Bulletin of the American Museum of Natural History, 186 (1): 1-101.

[2] Deckert K., Deckert G., Freytag G.E., Gunther K., Peters G., Sterba G. 1991. Fische, Lurche, Kriechtiere. In: Die große farbige Enzyklopädie Urania Tierreich, Leipzig; Jena; Berlin (Urania Verlag), 560-729.

[3] Zug G.R. 1971. Buoyancy, locomotion, morphology of the pelvic girdle and hind limb, and systematics of cryptodiran turtles. Miscellaneous Publications Museum of Zoology, University of Michigan, 142: 1-98.

[4] Stuart L.B., Van Dijk P.P., Hendrie D.B. 2001. Photographic guide to the the turtles of Thailand, Laos, Vietnam and Cambodia. Design Group, Phnompenh, Cambodia.

[5] Kasparek M. 2001. The nile soft-shelled turtle, Trionyx triunguis, Towards an Action Plan for the Conservation in the Mediterranean. Report to the $21^{\text {st }}$ Meeting of the Standing committee of the Conservation of European Wildlife and Natural Habitats, Bern Convention, Germany, ss.10.

[6] Carroll R.L. 1987. Heleosuchus: an enigmatic diapsid reptile from the Late Permian or Early Triassic of southern Africa. Canadian Journal of Earth Sciences, 24: 664-667.

[7] Laurin M., Reisz R.R. 1995. A reevaluation of early amniote phylogeny. Zoological Journal of the Linnean Society, 113: 165-223.

[8] Lee M.S.Y. 1996. Correlated progression and the origin of turtles. Nature, 379: 812-815.

[9] Li C., Wu X., Rieppel O., Wang L., Zhao L. 2008. An ancestral turtle from the Late Triassic of southwestern China. Nature, 456: 497-501.

[10] Gaffney E.S. 1975. A phylogeny and classification of higher categories of turtles. Bulletin of the American Museum of Natural History, 155 (5): 387-436.

[11] Zardoya R., Meyer A. 1998. Complete mitochondrial genome suggests diapsid affinities of turtles. Proceedings of the National Academy of Sciences, USA, 95: 14226-14231.

[12] DeBraga M., Rieppel O. 1997. Reptile phylogeny and the interrelationships of turtles. Zoological Journal of the Linnean Society, 120: 281-354.

[13] Rieppel O., deBraga M. 1996. Turtles as diapsid reptiles. Nature, 384: 453-455.

[14] Benton M.J. 1997. Vertebrate palaeontology. Chapman and Hall, London.

[15] Liao C.H., Ho W.Z., Huang H.W., Kuo C.H., Lee S.C, Li S.S. 2001. Lactate dehydrogenase genes of caiman and Chinese soft-shelled turtle, with emphasis on the molecular phylogenetics and evolution of reptiles. Gene, 279: 63-7.

[16] Li C., Fraser N.C., Rieppel O., Wu X.C. 2018. A Triassic stem turtle with an edentulous beak. Nature, 560: 476-479.

[17] Hennig W. 1983. Stammesgeschichte der Chordaten. Forschritte in der Zoologischen Systematik und Evolutionsforschung, 2: 1-208.

[18] Lee M.S.Y. 1997. Pareiasaur phylogeny and the origin of turtles. Zoological Journal of the Linnean Society, 120: 197-280.

[19] Kumazawa Y., Nishida M. 1999. Complete mitochondrial DNA sequences of the green turtle and blue-tailed mole skink: statistical evidence for archosaurian affinity of turtles. Molecular Biology and Evolution, 16: 784-792.

[20] Mannen H., Tsoi S.C.M., Krushkal J.S., Li W.H., Li S.S.L. 1997. The cDNA cloning and molecular evolution of reptile and pigeon lactate dehydrogenase isozymes. Molecular Biology and Evolution, 14: 1081-1087. 
[21] Mannen H., Li S.S.L. 1999. Molecular evidence for a clade of turtles. Molecular Phylogenetics and Evolution, 13: 144-148.

[22] Kumar S., Hedges S.B. 1998. A molecular timescale for vertebrate evolution. Nature, 392: 917920.

[23] Gaffney E.S. 1990. The comparative osteology of the Triassic turtle Proganochelys, Bull. Amer. Mus. Nat. Hist., 194: 1-263.

[24] Barley, A.J,. Spinks P.Q, Thomson R.C., Shaffer, H.B. 2010. Fourteen nuclear genes provide phylogenetic resolution for difficult nodes in the turtle tree of life. Molecular Biology and Evolution, 55 (3): 1189-94.

[25] Rhodin A.G.J, van Dijk D.P.P., Parham J. F. 2008. Turtles of the world: annotated checklist of taxonomy and synonymy. In: Rhodin A. G. J., Pritchard P.C.H., van Dijk P.P., Saumure R.A., Buhlmann K.A., Iverson J.B. Conservation Biology of Freshwater Turtles and Tortoises: A Compilation Project of the IUCN/SSC Tortoise and Freshwater Turtle Specialist Group. Chelonian Research Monographs 5:000.1-000.38. www.iucn-tftsg.org/cbftt/.

[26] Romer A.S. 1956. Osteology of the reptiles. Univ. Chicago Press, Chicago, Illinois, 772 pp.

[27] Hirayama R., Brinkman D.B., Danilov I.G. 2000. Distribution and biogeography of non-marine Cretaceous turtles. Russian Journal of Herpetology, 7: 181-198.

[28] Lapparent de Broin F. 2000. African chelonians from the Jurassic to the present: phases of development and preliminary catalogue of the fossil record. Paleontologia Africana, 36: 43-82.

[29] Joyce W.G., Lyson T.R. 2010. A neglected lineage of North American turtles fills a major gap in the fossil record. Palaeontology, 53: 241-248.

[30] Meylan P.A., Gaffney E.S. 1992. Sinaspideretes is not the oldest trionychid turtle, Journal of Vertebrate Paleontology, 12: 257-259.

[31] Ernst C.H., Lovich J.E., Barbour R.W. 1994. Turtles of the United States and Canada. Smithsonian Institution Press, Washington and London, 578.

[32] Ernst C.H., Altenburg R.G.M., Barbour, R.W. 2000. World Biodiversity Database CD-ROM Series. Expert Center for Taxonomic Identification, Amsterdam, The Netherlands.

[33] Praschang P., Gemel R. 2002. Identity of the black softshell turtle Aspideretes nigricans (Anderson 1875) with remarks on related species. Faunistische Abhandlungen, 23: 87-116.

[34] Praschang P., Hundsdörfer A.K., Reza A.H.M.A., Fritz U. 2007. Genetic evidence for wild-living Aspideretes nigricans and a molecular phylogeny of South Asian softshell turtles (Reptilia: Trionychidae: Aspideretes, Nilssonia). Zoological Scripta, 36 (4): 301-310.

[35] Pritchard P.C.H. 1984. Piscivory in turtles, and evolution of the long-necked Chelidae. Symposia of the Zoological Society of London, 52: 87-110.

[36] Webb R.G. 1962. North American Recent soft-shelled turtles (Family Trionychidae). University of Kansas Publications. Museum of Natural History Lawrence, 13 (10): 429-611.

[37] Mustoe G.E., Girouard S.P. 2001. A fossil trionychid turtle from the early Tertiary Chuckanut Formation of northwestern Washington. Northwest Science, 75: 211-218.

[38] Pritchard P.C.H., 2001. Observations on body size, sympatry, and niche divergence in softshell turtles (Trionychidae). Chelonian Conservation and Biology, 4: 5-27.

[39] Van D.P.P., Stuart B., Rhodin G.J. 2000. Asian Turtle Trade: Proceedings of a workshop on conservation and trade of freshwater turtles and tortoises in Asia. Chelonian Research Monographs, 2: 164.

[40] Iverson J.B. 1992. A revised checklist with distribution maps of the turtles of the World. Richmond, Ind. 363 p.

[41] Gaffney E.S. 1979. An introduction to the logic of phylogeny reconstruction. In: Cracraft J., Eldredge N. (eds), Phylogenetic Analysis and Paleontology, Columbia University Press, New York, 79-111.

[42] Chkhikvadze V.M. 2000. Fossil Trionychid turtles from the territory of the former SU. Forth Asian Herpetological Meeting, Tbilisi, Georgia.

[43] Engstrom T.N, Shaffer H.B., McCord W.P. 2004. Multiple datasets, high homoplasy and the phylogeny of softshell turtles. Systematic Biology, 53 (5): 693-710.

[44] Lapparent de Broin F. 2001. The European turtle fauna from the Triassic to the Present. Dumerilia, 4: 155-217. 
[45] Danilov Y.G. 2005. Die fossilen Schildkröten Europas. s.. In: Fritz U. (Hrsg.), Handbuch der Reptilien und Amphibien Europas. Band 3/IIIB: Schildkroten II. Wiebelsheim (Aula), 329-441.

[46] Joyce W.G, Lyson T.R. 2010. A neglected lineage of North American turtles fills a major gap in the fossil record, Palaeontology, 53 (2): 241-248.

[47] Dollo L. 1884. Premiere note sur les Cheloniens de Bernissart. Bulletin de Musee royal d'Histoire Naturelle de Belgique, 3: 63-79.

[48] Boulenger G.A. 1889. Catalogue of the Chelonians, Rhynchocephalians, and Crocodiles in the British Museum (Natural History), London: Trustees of the Museum, 311 pp.

[49] Siebenrock F. 1909. Synopsis der rezenten Schildkröten mit Berücksichtigung der in historischer Zeit ausgestorbenen Arten. Zoologische Jahrbücher Supplement, 10: 427-618.

[50] Bergoinioux F.M. 1955. Chelonia, Traite de Paleontologie. 5: 487-544.

[51] McDowell S.B. 1961. On the major arterial canals in the ear-region of testudinoid turtles and the classification of the Testudinoidea. Bulletin of the Museum of Comparative Zoology at Harvard College, 125 (3): 23-39.

[52] Gaffney E.S. 1984. Historical analyses of theories of chelonian relationship. Systematic Zoology, 33 (3): 283-301.

[53] Pritchard P.C.H. 1967. Living turtles of the world. T. F. H. Publ., Inc., Jersey City, New Jersey, $288 \mathrm{pp}$.

[54] Joyce W.G., Parham J.F., Gauthier J.A. 2004. Developing a protocol for the conversion of rankbased taxon names to phylogenetically defined clade names, as exemplified by turtles. Journal of Paleontology, 78 (5): 989-1013.

[55] Shaffer H.B., Meylan P., McKnight M.L. 1997. Tests of turtle phylogeny: molecular, morphological, and paleontological approaches. Systematic Biology, 46 (2): 235-268.

[56] Starkey D.E. 1997. Molecular systematics and biogeography of the New World turtle genera. Ph.D. dissertation, Department of Trachemys and Kinosternon, A\&M University, Texas, USA.

[57] Fujita M.K., Engstrom T.N., Starkey D.E., Shaffer H.B. 2004. Turtle phylogeny: insights from a novel nuclear intron. Molecular Phylogenetics and Evolution, 31: 1031-1040.

[58] Albrecht P.W. 1967. The cranial arteries and cranial arterial foramina of the turtle genera Chrysemys, Sternotherus, and Trionyx: a comparative study with analysis of possible evolutionary implications. Tulane Studies in Zoology, 14: 81-99.

[59] Zug G.R. 1971. Buoyancy, locomotion, morphology of the pelvic girdle and hindlimb, and systematics of cryptodiran turtles. Miscellaneous publications (University of Michigan, Museum of Zoology), 142: 1-98.

[60] DeBroin F. 1977. Contribution à l'étude des Chéloniens; Chéloniens continentaux du Crétacé et du Tertiaire de France. Mémoires du Muséum National d'Histoire Naturelle Serie, 38: 1-366.

[61] Hummel K. 1929. Die fossilen Weichschildkroten (Trionychia). Eine morphologischsystematische und stammesgeschichtliche Studie. Geologische und Palaenotologische Abhandlungen, 16: 359-487.

[62] Loveridge A., Williams E.E. 1957. Revision of the African tortoises and turtles of the suborder Cryptodira. Bulletin of the Museum of Comparative Zoology at Harvard College, 115: 163-557.

[63] Engstrom T.N., Shaffer H.B., McCord W.P. 2002. Phylogenetic diversity of endangered and critically endangered southeast Asian softshell turtles (Trionychidae: Chitra). Biological Conservation, 104: 173-179.

[64] Ernst C.H., Barbour R.W. 1989. Turtles of the World. Smithsonian Inst. Press, Washington, D.C., 290-313.

[65] Li H., Liu J., Xiong L., Zhang H., Zhou H, Jing W., Li J., Shi Q., Wang Y., Liu J., Nie L. 2017. Phylogenetic relationships and divergence dates of softshell turtles (Testudines: Trionychidae) inferred from complete mitochondrial genomes. Journal of Evolutionary Biology, 30: 1011-1023.

[66] Taşkavak E., Reimann M.J., Polder W.N. 1999. First record of Trionyx triunguis from Kos Island, Greece with comments on its occurrence in the eastern Mediterranean. Chelonian Conservation and Biology, 3 (3): 510-512.

[67] Kasparek M. 2001. Towards an Action Plan for the Conservation of the Nile soft-shelled turtle, Trionyx triunguis in the Mediterranean. Report to the 21st Meeting of the Standing Committee of the Convention on the Conservation of European Wildlife and Natural Habitats (Bern Convention), Bern, Germany, 1-10. 
[68] Taşkavak E., Akçınar S.C. 2007. Nil Yumuşak Kabuklu Kaplumbağası Trionyx triunguis (Forsskal, 1775), Ege ve Akdeniz'den Yeni Kayıtları. XIV. Ulusal Su Ürünleri Sempozyumu, Muğla.

[69] Kasparek M., Kinzelbach R. 1991. Distribution and bionomics of the Nile soft-shelled turtle, Trionyx triunguis, in the Eastern Mediterranean. Zeitschrift für Angewandte Zoologie, 78: 137159.

[70] Spawls S., Howell K., Drewes R., Ashe J. 2002. A field guide to the reptiles of east Africa. Academic Press, New York, 543 s.

[71] Caspary H.U., Mertens A.D., Niagaté B. 1998. Possibilites d'une Exploitation Durable des Ressources Fauniques dans la Réserve de Faune du Bafing. Eschborn, Germany.

[72] Hinkel H., Fischer E. 1988. Reptiles et Amphibiens du Rwanda et leurs environnemenl. Naturwissen schaftliche Forschungsgruppe Zentral-\& Ost-Africa. Johannes Gutenberg Universilal, Mainz; Bureau de Coordination, Kigali.

[73] Nada M. 2002. An Assessment of the Nile soft-shelled turtle, Trionyx triunguis, in the Nile Delta and its Lagoons, Egypt. Commissioned by The Mediterranean Association to Save the Sea Turtles (MEDASSET) and Supported by the British Chelonian Group (BCG). Final Report, 13.

[74] Venizelos L., Kasparek M. 2006. Trionyx triunguis: the brackish water turtle that also lives in the Mediterranean Sea. In: Frick, M., A. Panagopoulou, A. Rees, and K. Williams. Book of Abstracts 26th Annual Symposium on Sea Turtle Biology and Conservation, 168.

[75] Carlino P., Msayleb N., Hamza H., Pauwels O.S.G. 2019. A New Record of the Nile Soft-shelled Turtle, Trionyx triunguis, in Lebanon. Bulletin of the Chicago Herpetological Society, 54 (5): 101-103.

[76] Amer S.A., Kumazawa Y. 2009. Complete sequence of the mitochondrial genome of the endangered Nile soft-shelled turtle Trionyx triunguis. The Egyptian Journal of Experimental Biology (Zoology), 5: 43-50.

[77] Tuna V. 1988. The remains of a fossil Soft-shelled Turtle (Trionyx) from the Bayraktepe area (Turkey). Zoology in the Middle East, 2 (1): 63-67.

[78] Candan O. 2018. The Nile Softshell Turtle (Trionyx triunguis): Nest Parameters and A New Nesting Site. Acta Aquatica Turcica, 14 (4): 303-311.

[79] Burghardt G.M., Ward B, Rosscoe R. 1996. Problem of reptile play: Environmental enrichment and play behavior in a captive nile soft-shelled turtle, Trionyx triunguis. Zoo Biology, 15 (3): 223238.

[80] Keller M. 2005. Die Nil-Weichschildkröte, Trionyx triunguis in der Türkei - ein Überblick. Aktionsgemeinschaft Artensutz, 5: 1-7.

[81] Gidiş M., Kaska Y. 2004. Population size, reproductive ecology and heavy metals in the nile softshelled turtle (Trionyx triunguis) around thermal Kükürtlü lake, Muğla-Turkey. Fresenius Environmental Bulletin, 13 (5): 405-412.

[82] Bride I. 2004. Update Report on the Status of the Nile Soft-shelled Turtle, Trionyx triunguis, in Dalaman and Dalyan, Turkey. Report to the 24nd Meeting of the Standing Committee of the Convention on the Conservation of European Wildlife and Natural Habitats, MEDASSET, Bern, Germany.

[83] Kinzelbach R. 1986. Recent records of the Nile soft-shelled turtle, Trionyx triunguis, and of the Euphrates softshelled turtle, Trionyx euphraticus in the Middle East. Zoology in the Middle East, 1: 83-87.

[84] Baran I., Kasparek M. 1989. Marine Turtles Turkey: Status survey 1988 and recommendations for conservation and management. WWF, Kasparek Verlag, Heidelberg, Germany, $123 \mathrm{~s}$.

[85] Wilson D.S. 1998. Nest-site selection: Microhabitat variation and its effects on the survival of turtle embryos. Ecology, 79: 1884-1892.

[86] Medasset, 1999. Up-date report and rewiev of the status of the Nile soft-shelled Turtle (Trionyx triunguis) in Turkey. The Mediterranean Associaion to Save the Sea Turtles, Document T-PVS, 99: 73.

[87] Akçınar S.C., Taşkavak E. 2017. Population size and structure of the African Softshell Turtle, Trionyx triunguis, in Dalaman, southwestern Turkey. Zoology in the Middle East, 63 (3): 202209. 
[88] Güçlü Ö., Bozdoğan B. 2019. Genetic diversity and structure of the Nile Soft-Shelled Turtle (Trionyx triunguis) along the Mediterranean coast of Turkey. Russian Journal of Herpetology, in press.

[89] Gidiş M, Spinks P.Q., Çevik E., Kaska Y., Shaffer H.B. 2010. Shallow genetic divergence indicates a Congo-Nile riverine connection for the softshell turtle Trionyx triunguis. Conservation Biology, 12: 589-594.

[90] Güçlü O., Ülger C., Türkozan O., Gemmel R., Reimann M., Levy Y., Ergene S., Uçar A., Aymak C. 2009.First assessment of mitochondrial DNA diversity in the endangered Nile Softshell Turtle, Trionyx triunguis, in the Mediterranean. Chelonian Conservation Biology, 8 (2): 222-226.

[91] Güçlü O., Ülger C., Türkozan O. 2011. Genetic variation of the Nile Soft-Shelled Turtle (Trionyx triunguis). International Journal of Molecular Science, 12 (10): 6418-6431.

[92] Güçlü O., Durmuş S.H., Candan K., Beşer N., Türkyılmaz S., Yerli S., Bozdoğan B. 2015. Isolation and characterization of polymorphic microsatellite loci on Trionyx triunguis (Testudiniata: Trionychidae) in the mediterranean basin. Amphibia-Reptilia, 36: 318-324.

[93] Shanas U., Gidiş M., Kaska Y., Kimalov Y., Rosner O., Shlomo R. 2012. The Nile soft-shell turtle, Trionyx triunguis, of Israel and Turkey: Two genetically indistinguishable populations?, Zoology in the Middle East, 57: 61-68. 